\section{Infecção hospitalar por Pseudomonas a eruginosa multi-resistente: análise epidemiológica no HC-FMUSP}

\begin{abstract}
Pseudomonas aeruginosa permanece como um dos mais prevalentes agentes de infecções hospitalares em todo o mundo. A despeito dos avanços tecnológicos em relação ao desenvolvimento de drogas de maior potência antibacteriana, suas características naturais de resistência a mantém em papel de destaque referente às dificuldades terapêuticas. A microbiologia tem contribuído ao entendimento epidemiológico desses eventos ao identificar a origem clonal das bactérias, permitindo correlacionar eventuais fatores, como: colonização e infecção, contaminação ambiental e colonização, mudança do padrão de sensibilidade antimicrobiana, além de outros. Esses conhecimentos propiciam um melhor equacionamento de medidas de controle de infecção hospitalar. No segundo semestre de 1991, surgiram os primeiros casos de infecção hospitalar por cepas multi-resistentes, sensíveis apenas à colistina, no Hospital das Clínicas da Faculdade de Medicina da Universidade de São Paulo (HC-FMUSP). Motivados pela necessidade de conhecer o perfil epidemiológico das infecções por esse microorganismo, em relação a sua origem clonal e aos fatores relacionados ao seu aparecimento, foi realizado o presente trabalho, através de um estudo caso-controle. Todos os casos de infecção hospitalar por $P$. aeruginosa multi-resistente sensível apenas à colistina (15 casos), ocorridos de fevereiro a junho de 1992, foram pareados a 30 controles com infecção ou colonização por $P$. aeruginosa sensíveis a, pelo menos, dois aminoglicosídios e analisados quanto aos seus dados clínicos, epidemiológicos e laboratoriais (incluindo tempo de hospitalização, uso de antimicrobianos, número de procedimentos invasivos, uso de drogas imunossupressoras e gravidade da doença). As cepas isoladas dos casos foram estudadas no seu perfil de sensibilidade antimicrobiana por método de difusão em disco (Kirby-Bauer), método
\end{abstract}

\section{Nosocomial infection caused by multi-resistant Pseudomonas aeruginosa: epidemiological analysis at HC-FMUSP}

\begin{abstract}
Pseudomonas aeruginosa is one of the most prevalent causes of nosocomial infection in the World. Even the recent therapeutic advances have not solved the difficulties caused by antimicrobial resistance associated with this microorganism. Microbiologic studies have contributed to the understanding of epidemiologic factors associated with infection and colonization by $P$. aeruginosa, clonal origin, environmental contamination and shifts in antimicrobial susceptibility. All these resulted in a better understanding of the problem and helped to improve nosocomial infection control. The first cases of infections caused by multi-resistant gram negative bacilli occurred in our hospital during the second half of 1991. The objective of this study was to identify factors associated with multi-resistant $P$. aeruginosa (MRPA) infections and obtain data on their clonal origin. A case-control study was designed in which all nosocomial infections by MRPA (resistant to aminoglycosides, quinolones, betalactams including imipenem and aztreonam; only susceptible to colistin) at the Hospital das Clínicas da Faculdade de Medicina da Universidade de São Paulo from February to June 1992, were considered cases. Two controls were obtained for each case. Controls presented in infection or colonization by $P$. aeruginosa susceptible to at least 2 aminoglycosides. The following data were collected: length of hospitalization, antimicrobial use, invasive procedures, immunesupressive drugs, severity of underlying condition. Case strains (MRPA) were studied as to their antimicrobial susceptibility pattern using the Kirby-Bauer method, an automated method (Vitek-System) and broth microdilution. The strains were typed using phegotyping, pyocin typing, plasmid DNA analysis and chromosomal DNA analysis by contourclamped homogeneous electric field electrophoresis (CHEF). A longer hospital stay before the acquisition of $P$. aeruginosa, a
\end{abstract}

Recebido para publicação em 06/04/98. 
automatizado (Vitek-System) e microdiluição em caldo, além de fagotipagem, piocinotipagem, análise de DNA plasmidial e cromossômico por "Contor-clamped Homogeneous Electric Field Electrophoresis" (CHEF). As cepas dos controles foram estudadas no seu perfil de sensibilidade antimicrobiana através de método de difusão em disco. O tempo de permanência hospitalr prévio ao isolamento do microorganismo, a exposição a antibióticos, o uso de drogas imunossupressoras e a granulocitopenia apresentaram correlação, estatisticamente significante, com o desenvolvimento de infecção pelo microorganismo em questão. A comparação dos métodos de tipagem identificou, nas amostras oriundas do Instituto do Coração, tendência para isolamento de um único tipo de cepa, enquanto as amostras oriundas de outras unidades do Instituto Central identificou pelo menos 3 tipos de cepas. Em conclusão: Existem várias cepas de origem clonal diferente, disseminadas no complexo do HC-FMUSP, prevalecendo uma identidade genética no Instituto do Coração. Ocorre uma associação entre o uso de antimicrobianos e o maior tempo de permanência hospitalar previamente ao isolamento de microorganismo com as infecções hospitalares por Pseudomonas aeruginosa multi-resistente sensível apenas à colistina. É importante a utilização de mais de uma técnica destinada à tipagem de Pseudomonas aeruginosa multi-resistente sensível apenas à colistina, mesmo quando se dispõe da análise do DNA cromossomal por "Contour-clamped Homogeneous Electric Field Electrophoresis" ("CHEF"). A associação das técnicas de análise do DNA cromossomal por "Contour-clamped Homogeneous Electric Field Electrophoresis" (CHEF) é a associação de métodos de tipagem de maior poder discriminatório para estudos epidemiológicos de cepas de Pseudomonas aeruginosa multiresistente, sensível apenas à colistina. higher exposure to antimicrobial drugs, the use of immunesupressive drugs and granulocytopenia were significantly associated with MRPA infection. Typing methods obtained a variety of different patters withim the hospital, and in only one of the buildings (Incor) was there one predominant pattern. In short, there were various strains of MRPA with different clonal origins (except for one building in which one type predominated); antimicrobial use and the length of hospitalization were significantly associated with multi-resistant $P$. aeruginosa infection. The use of more than one method for $P$. aeruginosa typing was important, however DNA analysis using CHEF was the most discriminatory method is this study.

\section{Érico Antônio Gomes de Arruda}

Dissertação apresentada à Faculdade de Medicina da Universidade de São Paulo para obtenção do Título de Mestre.

São Paulo, SP, Brasil, 1996 